\title{
Emotion regulation requirements and affective forecasts regarding expected organizational changes
}

\author{
Bettina Kubicek $^{1^{*}}$, Erik Hoelzl ${ }^{2}$ and Christian Korunka ${ }^{1}$ \\ ${ }^{1}$ University of Vienna, Department of Applied Psychology: Work, Education, and Economy, Vienna, Austria \\ ${ }^{2}$ University of Cologne, Department of Sociology and Social Psychology, Cologne, Germany
}

\begin{abstract}
In organizational change processes, employees develop expectations of future events and make affective forecasts about their affective reactions to these events. When making such affective forecasts, people often project their current affect onto future events without considering the unique characteristics of the events. Although affective forecasts have been assessed in several applied settings, only a few studies have examined work contexts. Therefore, the objective of this study was to assess whether employees making work-related affective forecasts also rely on current affect. Moreover, the study investigated whether employees whose work frequently requires regulation of their emotions are less likely to project their current work-related affect into the future. Cross-sectional data gathered from 1610 Austrian eldercare workers supported these assumptions. Employees relied heavily on current affect when making work-related affective forecasts. However, employees who reported that their work demanded high levels of emotion regulation exhibited a weaker relationship between current affect and predicted affect. We suggest that these findings have implications for understanding and managing organizational change processes.
\end{abstract}

Keywords: organizational change, emotional responses, prediction, emotional regulation, employees

\section{Zahteve po regulaciji čustev in napovedi čustev glede pričakovanih organizacijskih sprememb}

\author{
Bettina Kubicek ${ }^{1}$, Erik Hoelzl ${ }^{2}$ in Christian Korunka ${ }^{1}$ \\ ${ }^{1}$ Univerza na Dunaju, Oddelek za uporabno psihologijo: delo, izobraževanje in ekonomija, Dunaj, Avstria \\ ${ }^{2}$ Univerza v Kölnu, Oddelek za sociologijo in socialno psihologijo, Köln, Nemčija
}

\begin{abstract}
Povzetek: Med procesi organizacijskih sprememb zaposleni razvijejo določena pričakovanja glede prihodnjih dogodkov in oblikujejo napovedi glede lastnih čustvenih reakcij v prihodnosti. Ko oblikujejo napovedi, ljudje pogosto projicirajo trenutna čustva na prihodnje dogodke brez upoštevanja nekaterih edinstvenih značilnosti teh dogodkov. Čeprav so napovedi čustev proučevali na številnih področjih, jih je le malo bilo izvedeno v delovnih okoljih. S tem razlogom, je bil namen pričujoče raziskave ugotoviti, ali napoved $\mathrm{z}$ delom povezanih čustev temelji na trenutnih čustvih. Nadalje je pričujoča raziskava proučevala, ali so tisti zaposleni, katerih delo pogosto zahteva regulacijo čustev, v manjši meri nagnjeni k projekciji trenutnih čustev na prihodnje dogodke. Prečna raziskava, ki je zajemala 1610 avstrijskih zaposlenih na področju nege in oskrbe starostnikov, je potrdila omenjene domneve. Pri oblikovanju napovedi o prihodnjih z delom povezanih čustev se zaposleni pogosto oprejo na trenutna čustva. Po drugi strani pa je pri tistih, katerih delo zahteva visoko stopnjo regulacije čustev, odnos med trenutnimi čustvi in napovedanimi šibkejši. Omenjeni rezultati imajo implikacije za razumevanje in upravljanje s procesi organizacijskih sprememb.
\end{abstract}

Ključne besede: organizacijske spremembe, čustveni odzivi, napovedovanje, uravnavanje čustev, zaposleni

\footnotetext{
"Naslov/Address: Bettina Kubicek, University of Vienna, Department of Applied Psychology: Work, Education, and Economy, Universitaetsstrasse 7,1010 Vienna, Austria, e-mail: bettina.kubicek@univie.ac.at
} 


\section{Emotion regulation requirements and affective forecasts regarding expected organizational changes}

In many work contexts, organizational change is becoming more the norm than the exception. Employees' expectations regarding upcoming changes and how they construe the future can have profound effects on the success of organizational change. One important aspect that contributes to the understanding of employees' behavior during organizational change processes is their affect (Gooty, Gavin, \& Ashkanasy, 2009; Kiefer, 2002, 2005; Liu \& Perrewé, 2005). Specifically, affective forecasts, i.e., anticipated future affects (Wilson \& Gilbert, 2003, 2005) should influence how employees experience and react to change processes. Because affective forecasts often are rooted in current affect (Gilbert, Gill, \& Wilson, 2002; Loewenstein, O’Donoghue, \& Rabin, 2003) and because employees often differ in their forecasts, a better understanding of work-related affective forecasts is important for the management of organizational change. For example, if employees are faced with a restructuring of departments, it is important for managers to know that some of the resistance to change displayed by the employees may be due to employees' projection of their current affect into the future. Disgruntled employees may be more opposed to change, and it is important for managers to take these differences between employees into account.

Several factors have been found to influence affective forecasts. Of particular interest to the current study is research that has shown that individuals with greater capacities for emotion regulation (i.e., the ability to manage their emotions and to cope with emotion-provoking situations) make more accurate affective forecasts (Dunn, Brackett, Ashton-James, Schneiderman, \& Salovey, 2007). Emotion regulation is, however, not only an individual characteristic but has also been conceptualized as a job requirement for human service work (Zapf, 2002). Some jobs demand more emotion regulation than others. To extend previous work on individual differences, we examined whether emotion regulation as a situative job requirement affects work-related affective forecasts. This question is particularly relevant for organizational changes in work environments with high emotion regulation requirements, such as health care or service work.

\section{Organizational change and affective forecasting}

Affect is a ubiquitous phenomenon in organizations (Barsade \& Gibson, 2007). Affect resides in the relationships among organizational members and accompanies everyday work activities, team meetings, and human resource decisions. The organization influences employees' thoughts and affects, but the individuals' thoughts and affects also influence the organization
(Brief \& Weiss, 2002). On the one hand, job conditions (e.g., daily hassles, time pressure, or exposure to physical threats; Brief \& Weiss, 2002), leaders (e.g., Sy, Côté, \& Saavedra, 2005), and organizational changes (e.g., Kiefer, 2005) influence employees' affect. On the other hand, employees' affect influences judgments (e.g., Robbins \& DeNisi, 1994), performance (e.g., Wright, Cropanzano, $\&$ Meyer, 2004), and reactions to organizational change processes (e.g., Mossholder, Settoon, Armenakis, \& Harris, 2000). Thus, affective processes are important in organizational practice and research.

As suggested by previous research (Kiefer, 2002, 2005), organizational change processes are particularly prone to influence, and be influenced by, employees' affect. Thus, organizational change is an important field of research in terms of affect in organizations; the importance of this field of research is further stressed by the fact that organizational change has become a common feature of work over the last decades (Dutton, Ashford, O’Neill, \& Lawrence, 2001; Kiefer, 2005). Organizations are increasingly engaged in multiple concurrent change processes that range from the restructuring of work teams to the implementation of new work concepts to farreaching transformations such as mergers or acquisitions. Consequently, organizational change can no longer be viewed as a discrete isolated event; rather, organizational change should be understood as an ongoing process (Kiefer, 2005). From this perspective, changes in organizations have become the norm, and employees are continuously confronted with multiple, sometimes competing, transformations (Bryant \& Cox, 2006).

Transformations in organizations involve not only cognitive appraisals but also emotional experiences (Kiefer, 2002). These transformations produce opportunities for both positive (e.g., hope; Mossholder et al., 2000) and negative emotions (e.g., fear and anger; Giæver \& Hellesø, 2010; Kiefer, 2005). Emotions may be particularly important during the initiation of change processes as the first information regarding the changes is disseminated because it is difficult for employees to assess the range and personal significance of the announced transformations. At this stage, the planned changes are likely to induce "mixed emotions that are anticipatory in nature" (Liu \& Perrewé, 2005, p. 267) and are based on employees' expectations of future outcomes (Tiedens \& Linton, 2001). Thus, in addition to the actual outcomes, the emotions associated with the expected outcomes may be important (e.g., Wilson \& Gilbert, 2003). In assessing organizational changes, employees are likely to rely on their predictions of how the changes will make them feel once the changes are implemented.

Such predictions about one's future affect are referred to as affective forecasts (for reviews see, e.g., Loewenstein \& Schkade, 1999; MacInnis, Patrick, \& Park, 2006; Wilson $\&$ Gilbert, 2003). Affective forecasts have been examined in several applied settings, e.g., decisions about products (Wang, Novemsky, \& Dhar, 2009), public transport (Pedersen, Friman, \& Kristensson, 2011), or food (Read \& van Leeuwen, 1998). However, only a few studies 
have been related to the work context (e.g., Woodzicka \& LaFrance, 2001). Within the broader picture of emotions in organizational change processes, we therefore focus on affective forecasts regarding expected organizational changes.

Affective forecasts are influenced by various circumstances, e.g., previous experiences with similar events, the current situation, and personal characteristics. In a process model of affective forecasting, Wilson and Gilbert (2003) suggested that affective forecasts begin with a mental representation of the event. People then assess their emotional reaction to the event as it is mentally represented. Based on this assessment, they make an affective forecast. For example, when considering an upcoming organizational change process, employees may form a mental image of a situation in which a new supervisor blocks their promotion opportunities. Employees would expect feelings of fear, anger, and frustration in such a situation, and these feelings would be translated into a forecast of the future event.

In this process of producing a forecast, four possible sources of variation can be distinguished. First, the mental representation of the event can be incomplete. For example, Woodzicka and LaFrance (2001) found that women mispredict their reactions to sexually harassing questions during job interviews. One reason for these mispredictions is that the women partly construe the interview as a situation that they could easily leave but found it difficult to leave when actually experiencing the situation. Second, the mental representation of the event is prone to framing effects. For example, people tend to focus only on those components that differentiate between the situations and not on the commonalities between the situations (Dunn, Wilson, \& Gilbert, 2003). Third, the assessment of emotional reactions to the mental representation of the event is based on memory or on affective theories; i.e., theories about which events evoke which emotions. Both of these sources can be fallible (see Robinson \& Clore, 2002 for a review).

Fourth, and most pertinent to the current study, the step from the assessment of emotional reactions to the final affective forecast involves a "correction for unique influences" (Wilson \& Gilbert, 2003, p. 354). Unique influences refer to the aspects in which the mental representation and the actual future situation differ and to the influence of these aspects on emotions. Because the circumstances in which the forecast is made and the future circumstances are usually different, people should adjust their predictions but often do not do so (Gilbert et al., 2002). The common phenomenon in which people base their predictions strongly on the current situation has been labeled 'projection bias' (Loewenstein et al., 2003) or 'presentism' (Gilbert et al., 2002).

Based on research on affective forecasting, we expected that projections of current affect onto future affect would also occur for work-related forecasts. In other words, we expected that predicted affect would closely correspond to current affect, despite the fact that the external circumstances were likely to change. We therefore hypothesized that current positive affect would show a positive relationship with predicted positive affect (hypothesis 1a) and that current negative affect would show a positive relationship with predicted negative affect (hypothesis 1b).

\section{Predicted affect regarding expected organizational changes and emotion regulation requirements}

In the workplace, predicted affect may not only be influenced by current affect but also by job demands, especially emotional job demands. Such demands can result from interactions with customers or patients in which employees are required to regulate their emotions (Hochschild, 1983). Such emotion regulation has been conceptualized as an external demand that arises from customer-employee interactions (Zapf, 2002). Job environments vary in terms of the extent and frequency with which they demand emotion regulation. These variations confront employees with different requirements for emotion regulation. For example, eldercare units differ in the composition of patients in terms of diseases and impairments. Therefore, in some units, nurses are more frequently confronted with situations that evoke emotions that should not be displayed to the care recipients and need to be suppressed or otherwise regulated.

Regulating one's emotions constitutes an effortful process. Altering the manner in which one would spontaneously behave requires self-control (Schmidt, Neubach, \& Heuer, 2007). According to the strength model of self-control (Baumeister, Bratslavsky, Muraven, \& Tice, 1998; Baumeister, Vohs, \& Tice, 2007; Muraven \& Baumeister, 2000), self-control is a finite resource that can be depleted when individuals attempt or are required to change the manner in which they would spontaneously behave (Schmidt et al., 2007). The depletion of an individual's self-control resources leads to impaired performance and other negative outcomes, such as emotional exhaustion (Hagger, Wood, Stiff, \& Chatzisarantis, 2010; Schmidt \& Neubach, 2007). Empirical findings generally support these propositions as they have documented associations between emotion regulation requirements and negative job outcomes (see Hülsheger \& Schewe, 2011 for a recent meta-analysis). Specifically, associations between emotion regulation requirements and job dissatisfaction (Cheung \& Tang, 2010; Côté \& Morgan, 2002), emotional exhaustion (Chau, Dahling, Levy, \& Diefendorff, 2009; Zapf \& Holz, 2006), depersonalization (Brotheridge \& Grandey, 2002), absenteeism (Diestel \& Schmidt, 2010), organizational turnover (Goodwin, Groth, \& Frenkel, 2011), and psychosomatic complaints (for a review see Zapf, 2002) have been demonstrated.

Based on research that has shown that emotion regulation requirements and negative job outcomes are related, we expected that employees in workplaces with high emotion regulation requirements would be 
more pessimistic about their future affect. We therefore hypothesized that emotion regulation requirements would be negatively related to predicted positive affect (hypothesis 2a) and positively related to predicted negative affect (hypothesis 2b).

\section{Emotion regulation requirements and reliance on current affect}

Beyond influencing the level of predicted affect, emotion regulation requirements may also alter the degree to which employees rely on their current affect when making forecasts. As outlined above, affective forecasts depend on the degree to which people correct for the unique characteristics of the future situation. Previous research has shown that situational factors influence such corrections. For example, Buehler und McFarland (2001) showed that forecasts about the enjoyment of upcoming holidays were less enthusiastic when participants considered how they felt on previous occasions. Wilson, Wheatley, Meyers, Gilbert, and Axsom (2000) showed that forecasts about the joy of seeing their favorite football team winning were more cautious when participants also considered other activities besides the game (e.g., going to class or meeting with friends).

In line with these findings, we argue that emotion regulation requirements should also generate more caution in projections of current affect to future events and reduce the relationship between current and predicted affect. Although some previous research has addressed emotion regulation and affective forecasting, that research adopted different perspectives. For example, Totterdell, Parkinson, Briner, and Reynolds (1997) investigated affective forecasting as a way of regulating future moods, Loewenstein (2007) examined people's predictions of the effectiveness of emotional regulation strategies, and Dunn et al. (2007) assessed whether emotional intelligence influences the accuracy of affective forecasts. To supplement these three approaches, we argue that emotion regulation requirements, as a situational job demand, should prompt employees to better account for the idiosyncrasies of future events. Employees who are frequently confronted with requirements to regulate their emotions should be more careful in predicting that their feeling in the future will be the same as their current feelings. When making forecasts about future affect, these employees should consider the fact that external factors may influence their affect and thus rely less heavily on current affect when making their predictions.

Based on research that has linked affective forecasting and individual emotion regulation capacity, we expected that situational emotion regulation requirements would influence work-related affective forecasts. We therefore hypothesized that emotion regulation requirements would moderate the relationship between current and predicted affect and weaken the relationships of both positive (hypothesis 3a) and negative affect (hypothesis 3b).

\section{Methods}

\section{Participants}

We chose the professional and organizational context of healthcare, more specifically eldercare, for our study. Over the last few decades, healthcare professionals have been confronted with a variety of organizational changes, such as downsizing, the implementation of new management strategies (Berg, 2006; Newman \& Lawler, 2009), and new technological devices (Lee, Yeh, \& Ho, 2002) that aim to reduce costs and increase efficiency. Moreover, eldercare workers are particularly prone to face emotion regulation requirements at work. Eldercare is typically characterized by long-term and intensive care relations between professional caregivers and care recipients. To maintain a positive emotional bond with the care recipients and their families, eldercare workers must exhibit a variety of emotion regulation strategies (Henderson, 2001), such as displaying positive emotions (e.g., joy, confidence etc.) and inhibiting the expression of negative emotions when dealing with patient deterioration or patient aggression (Gillespie, Barger, Yugo, Conley, $\&$ Ritter, 2011). The eldercare profession was therefore deemed to be an adequate field to study the forecasting of work-related affect and the moderating role of emotion regulation requirements.

Participants were recruited from 42 nursing homes or outpatient care organizations in the eastern part of Austria between November 2008 and March 2009. The participating organizations were both privately and publicly financed. A total of 3,314 questionnaires were distributed, and 1,803 were returned, resulting in a response rate of 54\%. Overall, 1610 participants provided complete data on the study variables. Among these study participants, 63\% were employed in nursing homes, and $37 \%$ were employed in outpatient care organizations. The sample was composed of $25 \%$ nurses, $47 \%$ orderlies, and $23 \%$ nursing aids $(5 \%$ neglected to indicate which professional group they belong to). Most respondents were female $(90 \%)$. Age was only assessed in terms of age ranges for confidentiality reasons; $15 \%$ of the participants were younger than 30 years of age, $25 \%$ were between 31 and 40 years of age, $42 \%$ were between 41 and 50 years of age, and $18 \%$ were 51 years of age or older. The average job tenure was relatively high at 10.48 years $(S D=8.44)$.

\section{Materials and procedures}

After informative meetings with the management or the head nurse of the organizations to outline the study and arrange its implementation, paper-pencil questionnaires were distributed to the nursing staff members during team meetings either by one of the researchers and a research assistants or by the head nurse. Employees were asked to fill out the questionnaire and to either return it to the researchers or post it in a special box in their ward or their organization's headquarters. Among other concepts 
(i.e., job stressors, job resources, team cohesion, team communication, commitment, job satisfaction, well-being, and psychosomatic health complaints), the questionnaire assessed the following variables:

Current work-related affect. We used items from the German adaption (Krohne, Egloff, Kohlmann \& Tausch, 1996) of the Positive and Negative Affect Schedule (PANAS; Watson, Clark, \& Tellegen, 1988). This scale has previously been used with different temporal instructions and was therefore considered suitable. Items assessing five positive (active, interested, strong, enthusiastic, determined) and five negative affective states (distressed, upset, irritable, nervous, afraid) were included in the questionnaire because these items were deemed to fit best with the daily work experiences of eldercare workers. Participants were asked, "With respect to your work in general, how do you currently feel?" and indicated their responses regarding the intensity of each affective state on a 5-point rating scale that ranged from 1 (not at all) to 5 (extremely). Factor analyses with principal component extraction of factors with eigenvalues greater 1 and varimax rotation revealed two clear factors. Factor loadings all exceeded .50 and averaged .79 for current positive affect and .73 for current negative affect. Items were combined to form scales for current positive affect $(\alpha=.86)$ and current negative affect $(\alpha=.77)$.

Expected organizational changes. We used 10 selfdevised items to assess expected organizational changes. Participants were asked to indicate the extent to which they expected changes to occur within one year's time in the following domains: work load (4 items), the number of patients to be cared for, the amount of documentation required, the amount of knowledge and skills required, and the frequency of changes in work-related technologies, organizational structures, and team compositions. The following five response alternatives were provided to rate these expected changes: will decrease strongly, will decrease slightly, will stay about the same, will increase slightly, and will increase strongly. We recoded the items such that 0 represented no change, 1 represented slight changes (increases or decreases), and 2 represented strong changes. In addition to rating the amount of expected changes in various domains, the study participants were also asked to appraise the expected changes by responding to the following item: "Overall, I assess the expected changes within the next year as...". The response format for this item ranged from 1 (very positive) to 3 (neutral) to 5 (very negative).

Predicted work-related affect. Immediately after answering these questions about expected organizational changes within the next year, participants were asked to predict how they would feel in the spring 2010 (i.e., about one year later). The same PANAS items listed above were used. Items were averaged to form scales for predicted positive affect $(\alpha=.91)$ and predicted negative affect $(\alpha=.86)$.

Emotion regulation requirements. Respondents completed the emotional dissonance subscale of the
Frankfurt Emotion Work Scales (FEWS 4.1; Zapf, Vogt, Seifert, Mertini, \& Isic, 1999). Although labeled "emotional dissonance" by the authors, the scale actually assesses the frequency with which employees are confronted with situations that require the regulation of emotions via the suppression or induction of emotions. Whether emotional dissonance (i.e., the discrepancy between emotions that are felt and those that are displayed) is actually experienced by employees depends on how their cope with emotion regulation requirements (see Bono \& Vey, 2005 for a critique of the operationalization of emotional dissonance). The subscale consists of five items. A sample item of this subscale is as follows: "In your job, how often do you have to display emotions that do not correspond to how you feel in the situation?" For each item, respondents indicated how frequently they were confronted with situations that required regulation of their emotions on 5point rating scales that ranged from 1 (very often) to 5 (very seldom/never). Answers were recoded such that higher values indicated greater emotion regulation requirements. A factor analysis with principal component extraction of factors with eigenvalues greater than 1 revealed one factor, and one item was excluded due to weak factor loading. The remaining four items were averaged to form a scale of emotion regulation requirements $(\alpha=.85)$.

Control variables. Because predicted affect may not only be influenced by emotion regulation requirements and current affect, we controlled for a number of additional variables. Age, gender, and job tenure (in years) were included as socio-demographic control variables. Time pressure and job control were included as job-related control variables. These variables were measured using 5 items for time pressure (e.g., "I often have to work on too many tasks at the same time") and 7 items for job control (e.g., "I can decide how to perform my work tasks") from a German self-report instrument for work analysis in hospitals (TAA; Büssing \& Glaser, 2002). Respondents specified their job control and time pressure responses on 5 -point rating scales that ranged from 1 (not at all) to 5 (to a very great extent). Both subscales showed satisfactory internal consistencies ( $\alpha=.80$ for job control and $\alpha=.84$ for time pressure).

\section{Results}

\section{Controlling for potential common method bias}

Because all study constructs were measured with selfreport scales, our findings may be inflated by common method bias (Podsakoff, MacKenzie, Lee, \& Podsakoff, 2003). We therefore submitted the data to a set of confirmatory factor analyses using AMOS 7.0 (Arbuckle, 1995-2006) to evaluate the instruments' factorial structures and address concerns about common method variance. The statistical methods suggested by Podsakoff et al. (2003) that were applicable to this study were 
Table 1. Results of the confirmatory factor analyses (CFA) for current positive and negative affect, predicted positive and negative affect and emotion regulation requirements

\begin{tabular}{|c|c|c|c|c|}
\hline Model & $\chi^{2}$ & $d f$ & CFI & RMSEA \\
\hline $\begin{array}{l}\text { 5-Factor model (differentiating current positive and negative affect, predicted } \\
\text { positive and negative affect and emotion regulation requirements) }\end{array}$ & $3073.58^{* *}$ & 242 & .86 & .09 \\
\hline 1-Factor model (including one single factor) & $12228.89^{* *}$ & 252 & .43 & .18 \\
\hline 6-Factor model (adding a method factor to the 5-factor model) & $3216.01^{* *}$ & 228 & .86 & .09 \\
\hline
\end{tabular}

Note. $N=1610$; Fit statistics are based on maximum likelihood estimation; CFI = Comparative Fit Index; RMSEA = Root Mean Square Error of Approximation.

${ }^{*} p<.05,{ }^{* *} p<.01$

employed to test for common method biases. Specifically, these methods were the Harman's single-factor test and the test of a latent method effect model. Harman's single-factor test assesses whether a single factor (i.e., the common method) accounts for all the variance in the data. The test of a latent method effect model involves adding an unmeasured latent factor with all the measures as indicators to the hypothesized factor structure; i.e., all items are allowed to load on their respective theoretical constructs and onto one additional latent method factor. To compare the hypothesized five-factor structure with the one-factor model and the six-factor method effect model, we assessed the chi-squared statistic, the comparative fit index (CFI), and the root mean square of approximation (RMSEA). Model estimation was based on maximum likelihood methods. In all models, latent factors were allowed to correlate.

First, we specified the five-factor model that allowed the items of the focal subscales (current positive and negative affect, predicted positive and negative affect, and emotion regulation requirements) to load only on their respective theoretical constructs. This model yielded the following fit statistics: $\chi^{2}=3073.58, d f=242$, $p<.001, \mathrm{CFI}=.86, \mathrm{RMSEA}=.09$. Compared to the five-factor model, the one-factor model representing Harman's single-factor test produced significantly worse fit statistics: $\Delta \chi^{2}=9155.31, \Delta d f=10, p<.001$ (see Table 1 for fit statistics). This finding argues in favor of the hypothesized five-factor structure. Furthermore, the sixfactor method effect model that allowed the items to load onto their respective theoretical constructs and onto the additional method factor (Podsakoff et al., 2003) also fit the data worse than the five-factor model: $\Delta \chi^{2}=142.43$, $\Delta d f=14, p<.001$ (see Table 1). Taken together, the findings suggest that common method variance was not a problem in our study.

Descriptive statistics for the core variables are displayed in Table 2. Data were screened for skewness and kurtosis, and these screens produced no cause for concern. Skewness ranged from -0.41 (current positive affect) to 1.12 (current negative affect). Kurtosis values ranged from -.31 (time pressure) to 1.43 (current positive affect).

\section{Expected organizational change}

We first assessed whether eldercare workers indeed expected organizational and work-related changes to occur within the next year. Overall, 97\% of the participants expected changes in at least one of the 10 domains assessed. That is, only $3 \%$ expected no changes at all within the next year. The descriptive statistics suggest that, on average, the study participants expected slight changes $(M=0.87$; $S D=0.49)$. The smallest changes were expected in terms of the time allowed for breaks $(M=0.63 ; S D=0.73)$, and the greatest changes were expected regarding the amount of documentation required $(M=1.13 ; S D=0.74)$. In general, the expected changes were appraised neutrally or slightly positively $(M=2.88 ; S D=0.85$ on the five-point scale).

Table 2. Descriptives of and correlations among study variables

\begin{tabular}{|c|c|c|c|c|c|c|c|c|c|}
\hline Variable & $M$ & $S D$ & 1 & 2 & 3 & 4 & 5 & 6 & 7 \\
\hline 1 Job tenure in years & 10.48 & 8.44 & & & & & & & \\
\hline 2 Time pressure & 3.12 & 0.83 & .01 & & & & & & \\
\hline 3 Job control & 3.23 & 0.67 & $-.05^{*}$ & $-.17^{* *}$ & & & & & \\
\hline 4 Current positive affect & 3.66 & 0.79 & $-.12^{* *}$ & $-.18^{* *}$ & $.24^{* *}$ & & & & \\
\hline 5 Current negative affect & 1.91 & 0.76 & -.02 & $.32^{* *}$ & $-.14^{* *}$ & $-.24^{* *}$ & & & \\
\hline 6 Predicted positive affect & 3.52 & 0.82 & $-.13^{* *}$ & $-.19^{* *}$ & $.20^{* *}$ & $.60^{* *}$ & $-.18^{* *}$ & & \\
\hline 7 Predicted negative affect & 1.97 & 0.81 & .00 & $.29^{* *}$ & $-.08^{* *}$ & $-.19^{* *}$ & $.50^{* *}$ & $-.24^{* *}$ & \\
\hline 8 Emotion regulation requirements & 2.72 & 0.99 & .04 & $.41^{* *}$ & $-.16^{* *}$ & $-.30^{* *}$ & $.32^{* *}$ & $-.23^{* *}$ & $.27^{* *}$ \\
\hline
\end{tabular}

Note. $N=1610$; Pearson correlations.

${ }^{*} p<.05,{ }^{* *} p<.01$ 
Table 3. Predicted positive affect regressed on current affect and emotion regulation requirements

\begin{tabular}{|c|c|c|c|c|c|}
\hline \multirow[b]{2}{*}{ Variable } & \multirow{2}{*}{$\frac{\text { Model } 1}{B}$} & \multirow{2}{*}{$\frac{\text { Model } 2}{B}$} & \multirow{2}{*}{$\frac{\text { Model } 3}{B}$} & \multicolumn{2}{|c|}{ Model 4} \\
\hline & & & & $B$ & $95 \% \mathrm{CI}$ \\
\hline Constant & $-0.25^{* * *}$ & $-0.14^{*}$ & $-0.14^{*}$ & $-0.16^{*}$ & {$[-0.28,-0.04]$} \\
\hline Gender $^{a}$ & $0.25^{* * *}$ & $0.15^{* *}$ & $0.15^{* *}$ & $0.14^{* *}$ & {$[0.04,0.25]$} \\
\hline Age $31-40$ years $^{b}$ & -0.08 & -0.08 & -0.08 & -0.08 & {$[-0.18,0.03]$} \\
\hline Age $41-50$ years & $-0.14^{*}$ & $-0.18^{* *}$ & $-0.18^{* *}$ & $-0.18^{* * *}$ & {$[-0.28,-0.08]$} \\
\hline Age $\geq 51$ years & $-0.20^{* *}$ & $-0.25^{* * *}$ & $-0.25^{* * *}$ & $-0.24^{* * *}$ & {$[-0.36,-0.12]$} \\
\hline Job tenure in years & $-0.01^{* * *}$ & -0.00 & -0.00 & -0.00 & {$[-0.01,0.00]$} \\
\hline Time pressure & $-0.17^{* * *}$ & $-0.07^{* *}$ & $-0.07^{* *}$ & $-0.07^{* *}$ & {$[-0.11,-0.02]$} \\
\hline Job control & $0.20^{* * *}$ & $0.06^{*}$ & $0.06^{*}$ & $0.06^{*}$ & {$[0.01,0.11]$} \\
\hline Current positive affect (POS) & & $0.58^{* * *}$ & $0.58^{* * *}$ & $0.59^{* * *}$ & {$[0.55,0.64]$} \\
\hline Current negative affect (NEG) & & -0.03 & -0.03 & -0.04 & {$[-0.09,0.01]$} \\
\hline $\begin{array}{l}\text { Emotion regulation requirements } \\
\text { (ERR) }\end{array}$ & & & -0.01 & -0.01 & {$[-0.04,0.03]$} \\
\hline POS x ERR & & & & $-0.08^{* * *}$ & {$[-0.12,-0.04]$} \\
\hline NEG $x$ ERR & & & & 0.02 & {$[-0.02,0.07]$} \\
\hline$R^{2}$ & .09 & .38 & .38 & & 39 \\
\hline$F$ & $22.91^{* * *}$ & $109.52^{* * *}$ & $98.54^{* * *}$ & & $65^{* * *}$ \\
\hline$\Delta R^{2}$ & & .29 & .00 & & 01 \\
\hline$\Delta F$ & & $375.17^{* * *}$ & 0.23 & & $77^{* * *}$ \\
\hline
\end{tabular}

Note. $N=1610$.

${ }^{\mathrm{a}}$ male $=0$, female $=1 ;{ }^{\mathrm{b}}$ dummy coded, Age $\leq 30$ years served as the reference category.

${ }^{*} p<.05,{ }^{* *} p<.01,{ }^{* * *} p<.001$

\section{Emotion regulation requirements and affective forecasts}

The hypotheses we examined were concerned with the relationships between predicted affect and current affect, the relationships between predicted affect and emotion regulation requirements, and the moderating effect of emotion regulation requirements. Two separate hierarchical regression analyses were conducted with predicted positive affect and predicted negative affect as criterion, respectively. In the first step, control variables were included in the regression equation ${ }^{1}$.

In the second step, current affect was added to test hypotheses $1 \mathrm{a}$ and $1 \mathrm{~b}$ pertaining to the projection of current affect. We included both current positive affect and current negative affect to control for possible crossover effects; e.g., the possibility that predicted positive affect was not only related to current positive affect but was also related to current negative affect. In the third step,

\footnotetext{
${ }^{1}$ Regression analyses were also conducted without including age, gender, job tenure, job control, and time pressure as control variables. The results of these regression analyses were identical to the results of the analyses that included the control variables.
}

the emotion regulation requirements were included to test hypotheses $2 \mathrm{a}$ and $2 \mathrm{~b}$ pertaining to the main effect of emotion regulation requirements. In the fourth step, the interaction terms between current affect and emotion regulation requirements were included to test hypotheses $3 a$ and $3 b$ pertaining to the moderating effect of emotion regulation requirements. We followed previous suggestions regarding moderated regression analyses (Aiken \& West, 1991). All predictors were standardized before forming the multiplicative interaction term. Additionally, we standardized the criteria (predicted positive affect and predicted negative affect) on the respective current affect to allow for interpretation of the intercept and for direct comparisons of current and predicted affect.

For predicted positive affect, the inclusion of current work-related affect significantly improved the model compared to the control variables alone, $\Delta R^{2}=.29$, $F(2,1600)=375.17, p<.001$. The inclusion of emotion regulation requirements did not improve the model significantly, $\Delta R^{2}=.00, \quad F(1,1599)=0.23, \quad p=.63$. However, the inclusion of the interaction terms did improve the model, $\Delta R^{2}=.01, F(2,1597)=9.76, p<.001$. All parameters are shown in Table 3.

In the final model (Model 4 in Table 3), predicted positive affect was strongly related to current positive 


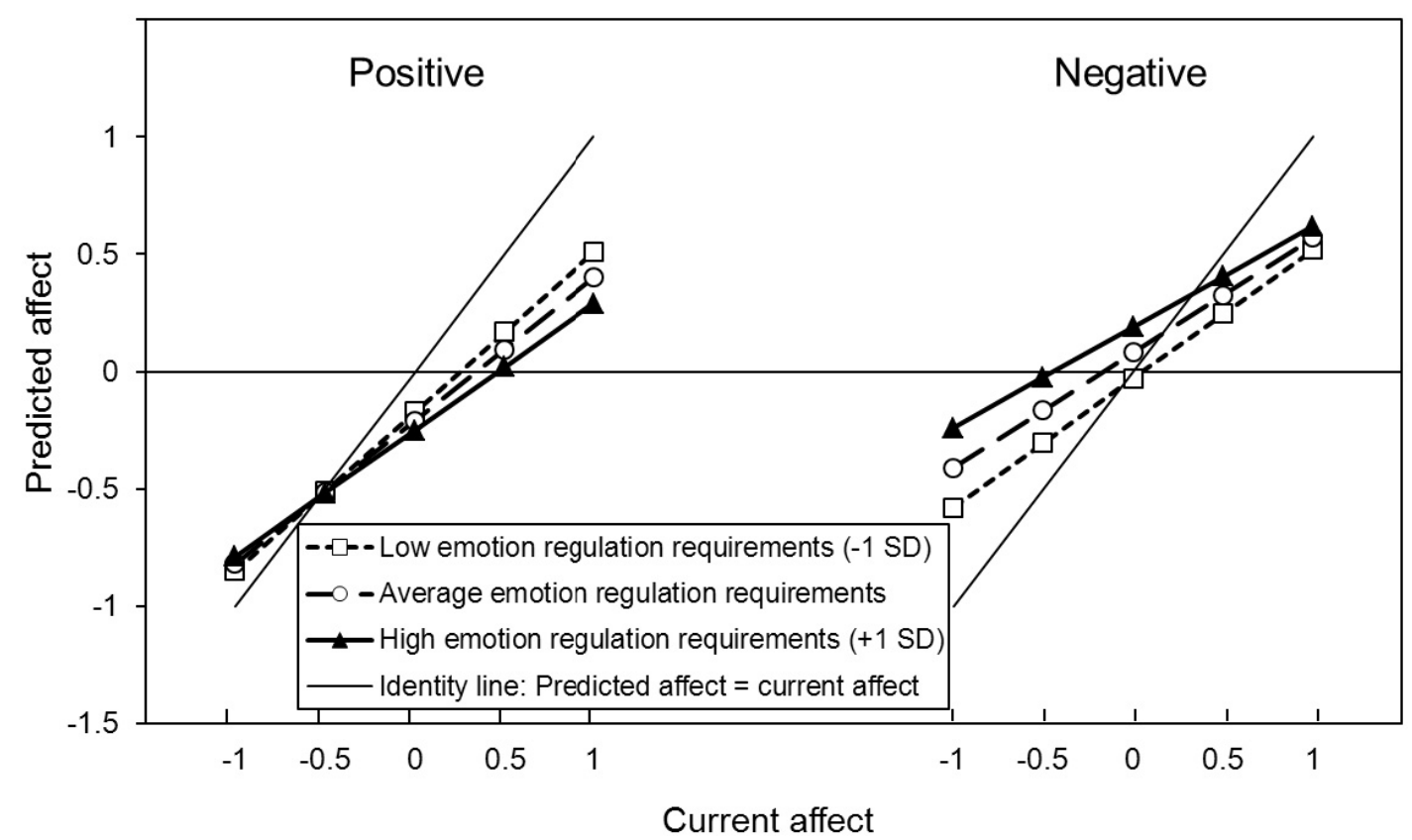

Figure 1. Predicted positive and negative affect as function of current affect and emotion regulation requirements.

$\operatorname{affect}(\mathrm{B}=0.59, p<.001)$ and not to current negative affect $(B=-0.04, p=.10)$. This finding supports hypothesis 1a, which states that employees would project their current affect onto the future. Overall, participants predicted general declines in positive affect (constant $B=-0.16$, $p<.05)$.

Emotion regulation requirements showed no effect $(B=-0.01, \quad p=.73)$, indicating that employees in workplaces with high emotion regulation requirements did not predict less positive affect in the future. Thus, hypothesis 2 a was not supported.

In support of hypothesis $3 \mathrm{a}$, the relationship between current and predicted positive affect was moderated by emotion regulation requirements in the expected direction $(B=-0.08, p<.001)$. Figure 1 (left panel) illustrates this interaction. For participants with high emotion regulation requirements at work, the slopes of the regression lines were less steep than those for participants with low emotion regulation requirements, moving the regression lines further away from the identity line. Subsequent simple slope analyses revealed a stronger relationship between current and predicted positive affect among employees with low emotion regulation requirements $(B=0.70, t(1606)=22.62, p<.001)$ compared to those with high emotion regulation requirements $(B=0.54$, $t(1606)=19.77, p<.001)$. Thus, the projection of current positive affect to predicted positive affect was weaker among employees who confronted greater emotion regulation requirements. No such interaction effect was found regarding current negative affect.

For predicted negative affect, a similar pattern of results emerged. The inclusion of current work-related affect significantly improved the model compared to the control variables alone, $\Delta R^{2}=.20, F(2,1600)=216.03$, $p<.001$. The inclusion of emotion regulation requirements further improved the model, $\Delta R^{2}=.009, F(1,1599)=9.47$, $p<.001$, as did the inclusion of the interaction terms, $\Delta R^{2}=.003, F(2,1597)=3.63, p<.05$. The parameters are shown in Table 4.

In the final model (Model 4 in Table 4), the predicted negative affect was strongly related to current negative affect $(B=0.49, p<.001)$ and weakly related to current positive affect $(B=-0.05, p<.05)$. These results support hypothesis $1 \mathrm{~b}$. Overall, participants predicted no changes in negative affect (Constant $B=-0.05, p=.46$ ).

However, a significant effect of emotion regulation requirements on predicted negative affect $(B=0.06$, $p<.01$ ) was found. In support of hypothesis $2 \mathrm{~b}$, participants with higher emotion regulation requirements predicted greater negative affect in the future.

The relationship between current and predicted negative affect was again moderated by emotion regulation requirements $(B=-0.06, p<.01)$, which supports hypothesis $3 \mathrm{~b}$. Subsequent simple slope analyses revealed that the projection of current negative affect to future negative affect was weaker for employees with high levels of emotion regulation requirements $(B=0.46$, $t(1606)=15.72, p<.001)$ compared to employees with low levels of emotion regulation requirements $(B=0.56$, $t(1606)=15.60, p<.001)$. For a graphical depiction of this interaction effect, see the right panel of Figure 1.

Taken together, the pattern of results illustrated in Figure 1 shows that the regression lines for employees with strong requirements for emotion regulation at work were less steep and, on average, further away from the identity lines for both positive and negative affect. Although the main effect of emotion regulation requirements was only supported in terms of negative affect (hypothesis 2b), 
Table 4. Predicted negative affect regressed on current affect and emotion regulation requirements

\begin{tabular}{|c|c|c|c|c|c|}
\hline \multirow[b]{2}{*}{ Variable } & \multirow{2}{*}{$\frac{\text { Model } 1}{B}$} & \multirow{2}{*}{$\frac{\text { Model } 2}{B}$} & \multirow{2}{*}{$\frac{\text { Model } 3}{B}$} & \multicolumn{2}{|c|}{ Model 4} \\
\hline & & & & $B$ & $95 \% \mathrm{CI}$ \\
\hline Constant & 0.08 & -0.04 & -0.05 & -0.05 & {$[-0.18,0.08]$} \\
\hline Gender $^{\mathrm{a}}$ & -0.04 & 0.02 & 0.04 & 0.04 & {$[-0.07,0.15]$} \\
\hline Age $31-40$ years $^{\mathrm{b}}$ & -0.01 & 0.01 & 0.01 & 0.01 & {$[-0.09,0.13]$} \\
\hline Age $41-50$ years & 0.00 & 0.09 & 0.09 & 0.10 & {$[-0.01,0.20]$} \\
\hline Age $\geq 51$ years & 0.05 & $0.15^{*}$ & $0.15^{*}$ & $0.15^{*}$ & {$[0.03,0.28]$} \\
\hline Job tenure in years & -0.00 & -0.00 & -0.00 & -0.00 & {$[-0.01,0.00]$} \\
\hline Time pressure & $0.27^{* * *}$ & $0.13^{* * *}$ & $0.10^{* * *}$ & $0.10^{* * *}$ & {$[0.06,0.15]$} \\
\hline Job control & -0.04 & 0.02 & 0.03 & 0.02 & {$[-0.03,0.08]$} \\
\hline Current positive affect (POS) & & $-0.07^{* *}$ & $-0.06^{*}$ & $-0.05^{*}$ & {$[-0.10,-0.01]$} \\
\hline Current negative affect (NEG) & & $0.49^{* * *}$ & $0.47^{* * *}$ & $0.49^{* * *}$ & {$[0.44,0.54]$} \\
\hline $\begin{array}{l}\text { Emotion regulation requirements } \\
\text { (ERR) }\end{array}$ & & & $0.06^{* *}$ & $0.06^{* *}$ & {$[0.02,0.10]$} \\
\hline POS x ERR & & & & -0.02 & {$[-0.06,0.02]$} \\
\hline NEG $\times$ ERR & & & & $-0.06^{* *}$ & {$[-0.10,-0.02]$} \\
\hline$R^{2}$ & .08 & .28 & .28 & & .29 \\
\hline$F$ & $20.94^{* * *}$ & $68.67^{* * *}$ & $63.07^{* * *}$ & & $3.34^{* * *}$ \\
\hline$\Delta R^{2}$ & & .20 & .00 & & .01 \\
\hline$\Delta F$ & & $216.03^{* * *}$ & $9.47^{* *}$ & & $3.63^{*}$ \\
\hline
\end{tabular}

Note. $N=1610$.

${ }^{\mathrm{a}}$ male $=0$, female $=1 ;{ }^{\mathrm{b}}$ dummy coded, Age $\leq 30$ years served as the reference category.

${ }^{*} p<.05,{ }^{* *} p<.01,{ }^{* * *} p<.001$

the interaction effect of emotion regulation requirements (hypotheses $3 \mathrm{a}$ and $3 \mathrm{~b}$ ) was fully supported by the data as was the relationship between current and predicted affect (hypotheses 1a and 1b).

\section{Discussion}

In the present study, we examined the effects of emotion regulation requirements on the work-related affective forecasts of eldercare workers. In line with the hypotheses we derived from the literature, we found that employees' forecasts were strongly related to their current affect, which corroborates earlier research on the reliance of affective forecast on current affect. Our results showed that employees make more negative forecasts about future affect when they frequently are required to regulate their emotions. That is, predicted negative work-related affect was greater among employees with high emotion regulation requirements. Additionally, emotion regulation requirements moderated the relationship between current and predicted affect. For employees whose work was characterized by high emotion regulation requirements, associations between predicted and current affect were still strong; however, these associations were significantly weaker than those observed in the employees whose work was characterized by low emotion regulation requirement, which supports the notion that the degree of reliance on current affect is reduced among employees who are strongly required to regulate their emotions.

\section{Theoretical implications}

From a theoretical perspective, our findings contribute to the understanding of affective forecasts. Previous research has demonstrated that people tend to strongly base their predictions on their current situation (Gilbert et al., 2002). This tendency has, however, been found to vary with personal factors (Dunn et al., 2007; Nielsen, Knutson, \& Carstensen, 2008; Totterdell et al., 1997). For example, the abilities to abstract from current affect and to foresee future affective reactions depend on individual emotion regulation competencies. According to Dunn et al. (2007), people are less likely to rely on current affect if they are competent in regulating their emotions. Because emotional regulation is not only a personal competence but also a work-related requirement, we assumed that emotion regulation requirements at work would also make people more likely to account for unique situational aspects. In accordance with this assumption, our results indicated that being frequently confronted with the job requirement of regulating one's emotions weakened the relationship 
between current and predicted affect. This finding supplements theoretical perspectives on the relationship between emotion regulation and affective forecasting. On the one hand, affective forecasts are a way of regulating future feelings (Totterdell et al., 1997). On the other hand, affective forecasts are influenced by emotion regulation competency (Dunn et al., 2007) and by emotion regulation requirements-as shown in our study. Investigating the complex relationships between affective forecasts and emotion regulation as both a personal competence and a situational demand seems to be a promising approach for future research. It will be interesting to investigate whether individual emotion regulation competencies and situational emotion regulation requirements reinforce each other in reducing employees' reliance on current affect when making affective forecasts. Moreover, it will be interesting to gain a deeper understanding of the temporal development of emotion regulation. On the one hand, accumulating experimental evidence demonstrates that regular exercise of self-regulation capabilities can foster employees' emotion regulation competencies (Oaten \& Cheng, 2006), suggesting that employees with high emotion regulation requirements develop individual competencies regarding the regulation of their emotions over time and that these competencies help them to make more accurate affective forecasts. On the other hand, the self-selection hypothesis (Breaugh, 1983) suggests that employees deliberately choose jobs that fit their individual competencies. Thus, employees with emotion regulation competencies may move into jobs that require more regulation of emotion. Testing these competing assumptions with longitudinally designed studies would deepen our understanding of the interplay between individual emotion regulation competencies, situational emotion regulation requirements and work-related affective forecasts.

\section{Practical implications}

Our findings show that what employees report about their future affect is strongly influenced by their current affect and also influenced and moderated by situational emotion regulation requirements. Because we asked participants to provide affective forecasts after reflecting on expected organizational change, we conjecture that our findings will be useful for deriving practical implications in the management of organizational change.

One of these implications could consider temporality. In an initial attempt to understand the temporal changes in work-related emotions, Liu and Perrewé (2005) differentiated between anticipatory (e.g., fear) and evaluative emotions (e.g., anger). According to their cognitive-emotional model of organizational change, anticipatory emotions are likely to emerge at the beginning of an upcoming change process when the personal consequences of the planned changes are not yet clear. When the change process is already underway, and the first changes have been implemented, employees are able to weigh the pros and cons of the situation. At this stage, employees' appraisals and the resulting emotions are more "evaluative" in nature (Liu \& Perrewé, 2005, p. 266). In addition to anticipatory (future-oriented) and evaluative (past-oriented) emotions, affective forecasts may be a third aspect of emotions that is relevant to the change process. While assessing the potential outcomes of the planned changes, employees are likely to rely on predictions of how these changes will make them feel after they will have been implemented. This predicted affect likely accounts for the overall appraisal of the upcoming change process and for the anticipatory emotions associated with it.

Our results show that employees' predictions of future work-related affect are strongly associated with their current affect. This finding suggests that employees who are already dissatisfied with their job will appraise the future less favorably and will project their negative affect onto upcoming changes. These employees are likely to predict that they will still feel negatively once changes have been implemented. Such negative affective forecasts may induce resistance to change and may hamper the implementation of planned transformations. Thus, in preparation of change processes, it may also be important to focus on employees' current work-related emotions.

For people in charge of organizational change processes, our finding that employees rely heavily on their current affect when predicting their affective reactions to expected changes has two important implications: First, it underscores the importance of employees' current affective states. The promise of positive changes may not be enough to convince employees of the benefits of upcoming transformations. Rather it seems necessary to change their current negative affective appraisal of their job to overcome potential resistance to change. Second, the strong relationship between current and predicted affect suggests that it may be of particular importance to consider individual differences when preparing employees for, and supporting them during, organizational transformations. Special emphasis should be placed on those employees who are currently dissatisfied with their job. These employees may not only thwart efforts to create a positive climate for organizational change in the work team or in the organization as a whole but may also consider leaving the organization if their outlook on the upcoming changes remains negative.

Finally, the positive relationship between emotion regulation requirements and predicted negative affect suggests that people in charge of organizational transformations also need to consider employees' current job demands. Change managers need to be sensitive to employees' current work situations. Change managers may improve workers' outlooks for their future in the organization by offering the work training that will help them meet their current job demands. Specifically, programs that seek to help employees to better manage their job demands, such as emotion regulation requirements, should reduce the employees' negative predictions about 
future work-related affect and should therefore indirectly contribute to more positive evaluations of upcoming changes.

\section{Limitations}

When assessing the results of this study, the following limitations should be considered. First, the moderating effect of emotion regulation requirements on the relationship between current and predicted affect appears weak. Indeed, after controlling for current affect, the interaction terms explained only approximately one additional percent of the variation in predicted affect. Nevertheless, this effect should be considered important because moderation effects are difficult to detect in field studies (McClelland \& Judd, 1993), and field study interactions typically account for $1 \%$ to $3 \%$ of the variance (Chaplin, 1991). Controlling for current affect, which was strongly correlated with predicted affect, made it even more difficult to detect moderator effects.

Second, this study focused on predicted affect only and did not allow for the evaluation of the accuracy of the predictions. Relying on current work-related affect when making predictions about future affect may be a reasonable and successful heuristic. Future studies should try to disentangle the relationship between current, predicted, and actual future affect and should study emotion regulation requirements as a predictor of accuracy in affective forecasts and as a moderator of this relationship.

Third, current and predicted affect were assessed at the same point in time, which may have contributed to carry-over effects that accounted for the high correlations between current and predicted affect. However, the results of statistical procedures that were used to test for common method biases suggest that the data were not affected by such biases and therefore lend support to the reliability of our findings. Moreover, we tried to reduce carry-over effects by separating the questions regarding current and predicted affect in the questionnaire. After indicating current affect, study participants were asked to provide information about team communication, commitment, job satisfaction, and expected organizational and workrelated changes before they were asked to rate their predicted affect. Thus, the questions regarding current and predicted affect were, at least, partially separated from each other. Nevertheless, future studies would benefit from introducing a temporal gap between the assessments of current and predicted affect.

\section{Conclusion}

In summary, the current study examined the role of emotion regulation requirements in the extent to which employees rely on current affect when making work-related affective forecasts regarding expected organizational changes. Our results indicate that, although employees' predictions about future work-related affect were heavily based on current affect, emotion regulation requirements were important. Not only did emotion regulation requirements increase predicted negative affect, they also moderated the association between current and predicted affect. Employees who were frequently confronted with emotion regulation requirements at work relied less heavily on current affect when forecasting their future workrelated affect. Therefore, both current affect and situative factors, such as emotion regulation requirements, need to be considered to understand and manage organizational change processes.

Acknowledgements: We are grateful to Filippo Cordaro for helpful comments. This project was funded by the Association of Viennese Social Services.

\section{References}

Aiken, L. S., \& West, S. G. (1991). Multiple regression: Testing and interpreting interactions. Newbury Park, CA, USA: Sage.

Arbuckle, J. L. (1995-2006). Amos 7.0.0. Spring House, PA, USA: Amos Development Corporation.

Barsade, S. G., \& Gibson, D. E. (2007). Why does affect matter in organizations? Academy of Management Perspectives, 21, 36-59.

Baumeister, R. F., Bratslavsky, E., Muraven, M., \& Tice, D. M. (1998). Ego depletion: Is the active self a limited resource? Journal of Personality and Social Psychology, 74, 1252-1265.

Baumeister, R. F., Vohs, K. D., \& Tice, D. M. (2007). The strength model of self-control. Current Directions in Psychological Science, 16, 351-355.

Berg, A. M. (2006). Transforming public services - transforming the public servant? International Journal of Public Sector Management, 19, 556-568.

Bono, J. E., \& Vey, M. A. (2005). Toward understanding emotional management at work: A quantitative review of emotional labor research. In C. E. J. Härtel, W. J. Zerbe, \& N. M. Ashkanasy (Eds.), Emotions in organizational behavior (pp. 213-233). Mahwah, NJ, USA: Lawrence Erlbaum Associates.

Breaugh, J. A. (1983). Realistic job previews: A critical appraisal and future research directions. Academy of Management Review, 8, 612-619.

Brief, A. P., \& Weiss, H. M. (2002). Organizational behavior: Affect in the workplace. Annual Review of Psychology, 53, 279-307.

Brotheridge, C. M., \& Grandey, A. A. (2002). Emotional labor and burnout: Comparing two perspectives of "people work". Journal of Vocational Behavior, 60(1), 17-39.

Bryant, M., \& Cox, J. W. (2006). The expression of suppression: Loss and emotional labour in narratives of organisational change. Journal of Management \& Organization, 12, 116-130. 
Buehler, R., \& McFarland, C. (2001). Intensity bias in affective forecasting: The role of temporal focus. Personality and Social Psychology Bulletin, 27, 1480-1493.

Büssing, A., \& Glaser, J. (2002). Das Tätigkeits- und Arbeitsanalyseverfahren für das Krankenhaus Selbstbeobachtungsversion (TAA-KH-S) [Activity and work analysis in hospitals - self-report version (TAA-KH-S)]. Göttingen, Germany: Hogrefe.

Chaplin, W. F. (1991). The next generation of moderator research in personality psychology. Journal of Personality, 59, 143-178.

Chau, S. L., Dahling, J. J., Levy, P. E., \& Diefendorff, J. M. (2009). A predictive study of emotional labor and turnover. Journal of Organizational Behavior, 30, 1151-1163.

Cheung, F., \& Tang, C. (2010). The influence of emotional dissonance on subjective health and job satisfaction: Testing the stress-strain-outcome model. Journal of Applied Social Psychology, 40(12), 3192-3217.

Côté, S., \& Morgan, L. M. (2002). A longitudinal analysis of the association between emotion regulation, job satisfaction, and intention to quit. Journal of Organizational Behavior, 23, 947-962.

Diestel, S., \& Schmidt, K. H. (2010). Interactive effects of emotional dissonance and self-control demands on burnout, anxiety, and absenteeism. Journal of Vocational Behavior, 77(3), 412-424.

Dunn, E. W., Brackett, M. A., Ashton-James, C., Schneiderman, E., \& Salovey, P. (2007). On emotionally intelligent time travel: Individual differences in affective forecasting ability. Personality and Social Psychology Bulletin, 33(1), 85-93.

Dunn, E. W., Wilson, T. D., \& Gilbert, D. T. (2003). Location, location, location: The misprediction of satisfaction in housing lotteries. Personality and Social Psychology Bulletin, 29, 1421-1432.

Dutton, J. E., Ashford, S. J., O’Neill, R., \& Lawrence, K. (2001). Moves that matter: Issue selling and organizational change. Academy of Management Journal, 44, 716-737.

Giæver \& Hellesø, R. (2010). Negative experiences of organizational change from an emotions perspective: A qualitative study of the Norwegian nursing sector. Nordic Psychology, 62(1), 37-52.

Gilbert, D. T., Gill, M. J., \& Wilson, T. D. (2002). The future is now: Temporal correction in affective forecasting. Organizational Behavior and Human Decision Processes, 88, 430-444.

Gillespie, J. Z., Barger, P. B., Yugo, J. E., Conley, C. J., \& Ritter, L. (2011). The suppression of negative emotions in elder care. Journal of Managerial Psychology, 26, 566-583.

Goodwin, R. E., Groth, M., \& Frenkel, S. J. (2011). Relationships between emotional labor, job performance, and turnover. Journal of Vocational Behavior, 79, 538-548.
Gooty, J., Gavin, M., \& Ashkanasy, N. M. (2009). Emotions research in OB: The challenges that lie ahead. Journal of Organizational Behavior, 30, 833-838.

Hagger, M. S., Wood, C., Stiff, C., \& Chatzisarantis, N. L. D. (2010). Ego depletion and the strength model of self-control: A meta-analysis. Psychological Bulletin, $136,495-525$.

Henderson, A. (2001). Emotional labor and nursing: An under-appreciated aspect of caring work. Nursing Inquiry, 8, 130-138.

Hochschild, A. R. (1983). The managed heart: Commercialization of human feeling. Berkeley: University of California Press.

Hülsheger, U. R., \& Schewe, A. F. (2011). On the costs and benefits of emotional labor: A meta-analysis of three decades of research. Journal of Occupational Health Psychology, 16(3), 361-389.

Kiefer, T. (2002). Understanding the emotional experience of organizational change: Evidence from a merger. Advances in Developing Human Resources, 4, 39-61.

Kiefer, T. (2005). Feeling bad: Antecedents and consequences of negative emotions in ongoing change. Journal of Organizational Behavior, 26, 875-897.

Krohne, H. W., Egloff, B., Kohlmann, C.-W. \& Tausch, A. (1996). Untersuchungen mit einer deutschen Form der Positive and Negative Affect Schedule (PANAS) [Studies with a German form of the Positive and Negative Affect Schedule (PANAS)]. Diagnostica, 42, 139-156.

Lee, T. T., Yeh, C.-H., \& Ho, L.-H. (2002). Application of a computerized nursing care plan system in one hospital: Experiences of ICU nurses in Taiwan. Journal of Advanced Nursing, 39, 61-67.

Liu, Y., \& Perrewé, P. L. (2005). Another look at the role of emotion in the organizational change: A process model. Human Resource Management Review, 15, 263-280.

Loewenstein, G. (2007). Affect regulation and affective forecasting. In J. J. Gross (Ed.), Handbook of emotion regulation (pp. 180-203). New York, NY, USA: The Guilford Press.

Loewenstein, G., O’Donoghue, T., \& Rabin, M. (2003). Projection bias in predicting future utility. The Quarterly Journal of Economics, 118, 1209-1248.

Loewenstein, G., \& Schkade, D. (1999). Wouldn't it be nice?: Predicting future feelings. In D. Kahneman, E. Diener, \& N. Schwarz (Eds.), Well-being: The foundations of hedonic psychology (pp. 85-105). New York, NY, USA: Russell Sage Foundation.

MacInnis, D. J., Patrick, V., \& Park, C. W. (2006). Looking through the crystal ball: Affective forecasting and misforecasting in consumer behavior. Review of Marketing Research, 2, 43-80.

McClelland, G. H., \& Judd, C. M. (1993). Statistical difficulties of detecting interactions and moderator effects. Psychological Bulletin, 114, 376-390. 
Mossholder, K. W., Settoon, R. P., Armenakis, A. A., \& Harris, S. G. (2000). Emotion during organizational transformations: An interactive model of survivor reactions. Group \& Organization Management, 25, 220-243.

Muraven, M., \& Baumeister, R. F. (2000). Self-regulation and depletion of limited resources: Does self-control resemble a muscle? Psychological Bulletin, 126, 247-259.

Newman, S., \& Lawler, J. (2009). Managing health care under New Public Management: A Sisyphean challenge for nursing. Journal of Sociology, 45, 419-432.

Nielsen, L., Knutson, B., \& Carstensen, L. L. (2008). Affect dynamics, affective forecasting, and aging. Emotion, 8, 318-330.

Oaten, M., \& Cheng, K. (2006). Improved self-control: The benefits of a regular program of academic study. Basic and Applied Social Psychology, 28(1), 1-16.

Pedersen, T., Friman, M., \& Kristensson, P. (2011). Affective forecasting: Predicting and experiencing satisfaction with public transportation. Journal of Applied Social Psychology, 41(8), 1926-1946.

Podsakoff, P. M., MacKenzie, S. B., Lee, J.-Y., \& Podsakoff, N. P. (2003). Common method biases in behavioral research: A critical review of the literature and recommended remedies. Journal of Applied Psychology, 88(5), 879-903.

Read, D., \& van Leeuwen, B. (1998). Predicting hunger: The effects of appetite and delay on choice. Organizational Behavior and Human Decision Process, 76(2), 189-205.

Robbins, T. L., \& DeNisi, A. S. (1994). A closer look at interpersonal affect as a distinct influence on cognitive processing in performance evaluations. Journal of Applied Psychology, 79, 341-353.

Robinson, M. D., \& Clore, G. L. (2002). Belief and feeling: Evidence for an accessibility model of emotional selfreport. Psychological Bulletin, 128, 934-960.

Schmidt, K. H., \& Neubach, B. (2007). Self-control demands: A source of stress at work. International Journal of Stress Management, 14, 398-416.

Schmidt, K. H., Neubach, B., \& Heuer, H. (2007). Selfcontrol demands, cognitive control deficits, and burnout. Work \& Stress, 21(2), 142-154.

Sy, T., Côté, S., \& Saavedra, R. (2005). The contagious leader: Impact of the leader's mood on the mood of group members, group affective tone, and group processes. Journal of Applied Psychology, 90, 295-305.

Tiedens, L. Z., \& Linton, S. (2001). Judgment under emotional certainty and uncertainty: The effects of specific emotions on information processing. Journal of Personality and Social Psychology, 81, 973-988.

Totterdell, P., Parkinson, B., Briner, R. B., \& Reynolds, S. (1997). Forecasting feelings: The accuracy and effects of self-predictions of mood. Journal of Social Behavior and Personality, 12, 631-650.
Wang, J., Novemsky, N., \& Dhar, R. (2009). Anticipating adaptation to products. Journal of Consumer Research, 36, 149-159.

Watson, D., Clark, L. A., \& Tellegen, A. (1988). Development and validation of brief measures of positive and negative affect: The PANAS scales. Journal of Personality and Social Psychology, 54(6), 1063-1070.

Wilson, T. D., \& Gilbert, D. T. (2003). Affective forecasting. In M. P. Zanna (Ed.), Advances in Experimental Social Psychology (Vol. 35 (pp. 345-411). San Diego, CA, USA: Academic Press.

Wilson, T. D., \& Gilbert, D. T. (2005). Affective forecasting; Knowing what to want. Current Directions in Psychological Science, 14(3), 131-134.

Wilson, T. D., Wheatley, T., Meyers, J. M., Gilbert, D. T., \& Axsom, D. (2000). Focalism: A source of durability bias in affective forecasting. Journal of Personality and Social Psychology, 78, 821-836.

Woodzicka, J. A., \& LaFrance, M. (2001). Real versus imagined gender harassment. Journal of Social Issues, 57, 15-30.

Wright, T. A., Cropanzano, R., \& Meyer, D. G. (2004). State and trait correlates of job performance: A tale of two perspectives. Journal of Business and Psychology, 18, 365-383.

Zapf, D. (2002). Emotion work and psychological wellbeing. A review of the literature and some conceptual considerations. Human Resource Management Review, 12, 237-268.

Zapf, D., \& Holz, M. (2006). On the positive and negative effects of emotion work in organizations. European Journal of Work and Organizational Psychology, 15(1), 1-28.

Zapf, D., Vogt, C., Seifert, C., Mertini, H., \& Isic, A. (1999). Emotion work as a source of stress: The concept and development of an instrument. European Journal of Work and Organizational Psychology, 8(3), 371-400. 